fellow teachers in programs on constitutional principles. The 1988 seminar for the James Madison Fellows was hosted by the Social Studies Development Center at Indiana University.

The 1988 James Madison Fellows will be following in the footsteps of an initial group of 20 teachers who have served as Fellows in 1986-87 and a larger group of 50 teachers who organized programs on the Bicentennial Year, 1987. All of these teachers established programs in communities that stretch from the Pacific Northwest through the South and up to the Far Northeast. They have prepared: features in local newspapers; special editions of student newspapers; exhibits and discussion groups in libraries; "constitution fairs" and town meetings; plays and dramatic readings; appearances on local television and radio stations. In addition, the James Madison Fellows have been sharing their knowledge and resources with their colleagues through extensive in-service workshops. The newly designated James Madison Fellows are expected to follow in their footsteps, thereby demonstrating the continuing strength of grass roots projects devoted to the Constitution's Bicentennial. The 1988 James Madison Fellows are:

Earl P. Bell, University Park, Illinois; The Laboratory Schools, University of Chicago; (3/2) 702-0588.

Donald E. Blankenbush, Pennington, New Jersey; John Witherspoon Middle School, Princeton. New Jersey; (609) $924-5600$.

Louis ]. Broccolo, New Lenox, Illinois; Central Junior High School, Tinley Park, Illinois; (3/2) 532-1771.

Sandra Shew Campbell, Arlington, Texas; Arlington High School; (817) 460-2541.

Lee A. Chase, Richmond, Virginia; Chesterfield County Public Schools, Chesterfield, Virginia; (804) 748- 1405.

James P. Garland, West Lafayette, Indiana; West Lafayette High School; (317) 743-9502.

Jeffrey A. Griffith, Fontana, California; Fontana High School; (7|4) 350-7500.

Joseph A. Lendini, Las Vegas, Nevada; Dell H. Robison Junior High School; (702) 799-7300.

Erma Gay McNinch, Brandon, Mississippi; Pearl High School, Pearl, Mississippi; (60l) 932-7931.
Shirley McDonnell, Beloit, Wisconsin; Hononegah Community High School, Rockton, Illinois; (815) 624-8951.

Edward M. Morris, Buckeystown, Maryland; Walt Whitman High School, Bethesda, Maryland; (30I) 320-5900.

Mary Murphy, State Representative, Hermantown. Minnesota; Minnesota House of Representatives, St. Paul, Minnesota: (218) 729-6399.

Michael F. Ortmann, Wichita, Kansas; Derby Middle School, Derby, Kansas; (316) 788-1559.

Linda N. Ryan, Ashland, Oregon; Co-Chair Ashland Bicentennial Committee, Liaison with Ashland School District; (503) 488-2828.

Ronald I. Savino, Simsbury, Connecticut; William H. Hall High School, West Hartford, Connecticut; (203) 232-4561.

Kenneth W. Townsend, Charlotte, North Carolina; Charlotte-Mecklenburg Schools; (704) 379-7000.

jill Wayne, Berwyn, Illinois; Kenwood Academy, Chicago, Illinois; (312) 536-8850.

\section{Tom Foley, Fred Holborn Honored at CFP Caucus Dinner}

The Honorable Thomas S. Foley was honored as the "Outstanding Legislator of the 100th Congress" and Professor Fred Holborn, of The Johns Hopkins University School for Advanced International Studies, as the "Outstanding Friend of the Program," at the third Congressional Fellowship Program Caucus. The two honorees were selected by former Fellows from among candidates nominated by the Congressional Fellowship Alumni Association's organizing committee. The awards were made at a dinner held September I at the Dupont Plaza Hotel, in Washington.

Leonard Parkinson, president of the Congressional Fellowship Alumni Association, was chairman of the event; he was assisted by Fred Clarke, vice president.

Congressional Fellowship Program caucus events are scheduled to coincide with APSA Annual Meetings held in Washington, DC. 